Огляди літератури, оригінальні дослідження, погляд на проблему, випадок з практики, короткі повідомлення УДК 593.121:579.83/.88:578]-043.5

DOI 10.11603/1811-2471.2019.v0.i2.10364

\title{
АКАНТАМЕБИ ЯК РЕЗЕРВУАР ПАТОГЕННИХ БАКТЕРІЙ ТА ВІРУСІВ (огЛЯД ЛіТератУРИ)
}

\section{Національний медичний університет імені О. О. Богомольця, Київ}

РЕЗюмЕ. Вільноживучі найпростіші роду Acanthamoeba $€$ представниками багатьох об'єктів зовнішнього середовища та постійно взаємодіють з іншими мікроорганізмами (вірусами і бактеріями), що населяють ці екологічні ніші. Особливості цих взаємовідносин вивчають дослідники з усього світу вже понад 20 років. Досліджено низку патогенних та умовно патогенних бактерій, які здатні співіснувати з акантамебами. Описано симбіотичну взаємодію амеб з ентеробактеріями, мікобактеріями, легіонелами, псевдомонадами, стафілококами, стрептококами та рядом інших прокаріот. Встановлено, що при співкультивуванні найпростіших з бактеріями збільшується термін виживання останніх та підвищується їх резистентність до впливу шкідливих факторів навколишнього середовища. Ряд наукових робіт присвячено також вивченню взаємодії Acanthamoeba sp. $з$ представниками царства Vira, а саме родів Adenovirus, Norovirus, Rotavirus та Enterovirus. Характер взаємодії бактерій та вірусів із представниками вільноживучих найпростіших на клітинному рівні досліджується найчастіше з використанням мікроскопічних та сучасних молекулярно-генетичних методів.

Мета - аналіз здатності вільноживучих амеб взаємодіяти з бактеріями та вірусами, а також виконувати роль резервуара для патогенних мікроорганізмів.

Висновок. Детальний аналіз літературних джерел дозволив зробити висновок, що вільноживучі амеби здатні активно поглинати патогенні мікроорганізми. Доведено також, що вільноіснуючі найпростіші можуть виконувати роль резервуара для патогенних мікроорганізмів та слугувати вектором передачі збудників інфекційних захворювань. Таким чином, амеби виконують роль «троянського коня» мікробного світу.

ключові словА: Acanthamoeba sp.; співіснування; бактерії; віруси.

Вступ. Акантамеби - вільноживучі найпростіші, які мають убіквітарне поширення та населяють різноманітні екосистеми, такі як ґрунт, вода, повітря. Вони були ізольовані із басейнів, водопровідних мереж, охолоджувальних та стоматологічних установок, апаратів для гемодіалізу, медичних засобів (рідина для лінз) тощо [1, 2]. Серед вільноживучих амеб тільки чотири роди включають умовно-патогенних для людини та тварин представників: Acanthamoeba, Balamuthia, Naegleria i Sappinia. Ïх таксономічне положення кілька разів переглядали відповідно до критеріїв сучасної систематики. Опираючись на класифікацію, запропоновану Міжнародним товариством протозоологів, ці мікроорганізми були віднесені до так званих "супергруп". Acanthamoeba та Balamuthia були віднесені до супергрупи Amoebozoa: Acanthamoevidae; Naegleria fowleri до Excavata: Heterolobosia: Vahlkampfiidae; і Sappinia до Amoebozoa: Flabellinea: Thecamoevidae [2]. Вільноживучі амеби здатні викликати такі захворювання у людей як: амебний кератит, гранулематозний енцефаліт, менінгіт та менінгоенцефаліт, синусити, шкірні ураження тощо [2-6].

Більшість вільноживучих амеб мають дві морфологічні форми: вегетативну - трофозоїт, і неактивну - циста. Вичерпання поживних речовин в осередку перебування амеб або дія інших екологічних стресових факторів, таких як зміна $\mathrm{pH}$, температури, насиченості киснем середовища, різке зменшення вологості сприяють перетворенню трофозоїтів у цисти. Цей процес називається інцистуванням. Цисти амеб стійкі до ряду несприятливих фізико-хімічних факторів - зрілі цисти вільноживучих амеб більш стійкі до дезінфікуючих засобів та біоцидів, ніж трофозоїти [7].

Взаємодія акантаме6 з бактеріями. Під час дослідження вільноживучих найпростіших було виявлено низку бактерій та вірусів, які можуть перебувати всередині амебної клітини. Описана специфічна здатність амеб захоплювати мікроби та зберігати їх у цитоплазмі, захищаючи таким чином від стресових чинників навколишнього середовища $[1,2]$. Як відомо, еукаріотичні клітини можуть поглинати речовини шляхом піноцитозу (в розчиненому стані) та фагоцитозу (в твердому стані). Останній, як правило, здійснюється при розмірах часток $\leq 250$ нм, включаючи клітини бактерій та інші клітини-мішені [8]. Зважаючи те, що акантамеби захоплюють мікроорганізми шляхом фагоцитозу, було висунуто припущення про спільну функціональну еволюцію амеб і компонентів мікромакрофагальної системи багатоклітинних організмів, безпосередньо макрофагів. Експериментальні роботи показали подібність даних типів клітин за ультраструктурними морфологічними особливостями, біохімічними властивостями, здатністю до активного руху та використанням псевдоподій для захоплення твердих часток [9]. Описане застосування вільноживучих найпростіших як моделі для дослідження явища фагоцитозу в умовах in vitro [10]. Maisonneuve E. et al. на прикладі аденові- 
Огляди літератури, оригінальні дослідження, погляд на проблему, випадок з практики, короткі повідомлення русів, з використанням мікроскопічних та молекулярно-генетичних методів, показали, що реплікація вірусу відбувається лише в макрофагах та відсутня в акантамебах. Також встановлено, що наявність вірусу знижує життєздатність макрофагів та не впливає на амеби. Саме тому найпростіших не можна використовувати як повністю адекватну модель для вивчення фагоцитозу [11].

На основі цього ряд авторів зробили висновок, що амеби є природним резервуаром різноманітних інфекційних чинників та діють як «троянські коні» мікробного світу $[12,13]$. Досліджена взаємодія найпростіших з легіонелами, ентеробактеріями, псевдомонадами, мікобактеріями та рядом інших бактерій. Для цих мікроорганізмів також був введений термін «амеборезистентні бактерії» (АРБ), завдяки їх здатності протистояти фагоцитозу амеб $[1,12,13]$. Описано понад 100 збудників інфекційних захворювань людини, які здатні тривалий час виживати й навіть розмножуватися при спільному існуванні з різними видами амеб. Деякі види бактерій можуть уникати дії високих концентрацій дезінфікувальних та антибактеріальних засобів, перебуваючи в трофозоїтах чи цистах найпростіших. У таблиці 1 наведені основні представники патогенних та умовно-патогенних бактерій, які можуть використовувати вільноживучих найпростіших як хазяїв.

Таблиця 1. Патогенні та умовно-патогенні мікроорганізми, які взаємодіють з найпростішими

\begin{tabular}{|c|c|c|}
\hline Родина & Вид & Літературні джерела \\
\hline \multirow{3}{*}{ Enterobacteriaceae } & Escherichia coli & $\begin{array}{l}\text { Matin A. et al. [14] } \\
\text { Somorin Y. et al. [15] }\end{array}$ \\
\hline & $\begin{array}{l}\text { Salmonella enterica: } \\
\text { serovar Dublin } \\
\text { serovar Enteritidis } \\
\text { serovar Typhimurium } \\
\text { serovar Typhi }\end{array}$ & $\begin{array}{l}\text { Tezcan-Merdol D. et al. [16] } \\
\text { Douesnard-Malo F. et al. [17] }\end{array}$ \\
\hline & $\begin{array}{l}\text { Shigella dysenteriae } \\
\text { Shigella sonnei } \\
\text { Shigella flexneri } \\
\end{array}$ & $\begin{array}{l}\text { Saeed A. et al. [18] } \\
\text { Saeed A. et al. [19]18 }\end{array}$ \\
\hline Legionellaceae & Legionella pneumophila & $\begin{array}{l}\text { Anand C. et al. [20] } \\
\text { King C. H. et al. [21] } \\
\text { Mengue L. et al. [22] } \\
\text { Adeleke A. et al. [23] }\end{array}$ \\
\hline \multirow{5}{*}{ Mycobacteriaceae } & Mycobacterium tuberculosis & Mba Medie F. et al. [24] \\
\hline & Mycobacterium avium & Samba-Louaka, A. et al. [25] \\
\hline & Mycobacterium leprae & Wheat W. et al. [26] \\
\hline & Mycobacterium smegmatis & Lamrabet O. et al. [27] \\
\hline & Mycobacterium bovis & Sanchez-Hidalgo A. et al. [28] \\
\hline Pseudomonadaceae & Pseudomonas aeruginosa & $\begin{array}{l}\text { Pukatzki S. et al. [29] } \\
\text { Dey R. et al. [30] }\end{array}$ \\
\hline Staphylococcaceae & $\begin{array}{l}\text { Methicillin-Resistant } \\
\text { Staphylococcus aureus } \\
\text { (MRSA) }\end{array}$ & Souza T. K. et al. [31] \\
\hline Streptococcaceae & $\begin{array}{l}\text { Streptococcus pneumoniae } \\
\text { Streptococcus pyogenes }\end{array}$ & Siddiqui R. et al. [32] \\
\hline Vibrionaceae & Vibrio cholerae & $\begin{array}{l}\text { Abd H., et al. [33] } \\
\text { Abd H., et al. [34] }\end{array}$ \\
\hline
\end{tabular}

Родина Enterobacteriaceae. Симбіотичні взаємовідносини між ентеробактеріями та вільноживучими амебами було досліджено на прикладі багатьох представників різних родів цієї родини.

Pid Escherichia. Для дослідження здатності акантамеб поглинати та зберігати бактерії роду Escherichia їх культивували спільно з Escherichia coli K1, K5 та K12. Після обробки антибіотиками визначали життєздатність бактерій. Різке зменшення або повна відсутність чутливості ешерихій до протимікробних лікарських засобів свідчили про можливість їх потрапляння всередину амебної клітини $[14,15]$. В результаті було показано, що штами К1 та К5 при поглинанні амебною клітиною залишалися життєздатними у внутрішньому клітинному середовищі та навіть могли роз- 
Огляди літератури, оригінальні дослідження, погляд на проблему, випадок з практики, короткі повідомлення

множувалися. Було виявлено, що зовнішній мембранний білок А (OmpA) і ЛПС клітинної стінки бактерій є вирішальними детермінантами, що відповідають за можливість поглинання амебою E. coliK1 [14]. Штам K12 після захоплення амебою повністю перетравлювався, саме тому цей тип E. coli застосовують у якості годувальників для культивування деяких найпростіших [3]. Таким чином було показано, що окремі штами $E$. coli спроможні виживати всередині акантамеб та використовувати їх як резервуар.

Pid Salmonella. Співкультивування бактерій виду Salmonella enterica: серовари typhi, typhimurium, enteritidis та dublin з вільноживучими амебами доводить наявність симбіотичних відносин між цими мікроорганізмами. Це явище підтверджене такими методами як проточна цитофлуориметрія, флуоресцентна та електронна мікроскопія. Показано, що бактерії після тривалого співкультивування з найпростішими зберігають свою життєздатність. Результати, представлені авторами, переконливо доводять, що при культивуванні S. enterica серовар typhi спільно 3 A. castellanii бактерії можуть зберігати свою життєздатність протягом 3 тижнів при температурі $30{ }^{\circ} \mathrm{C}$ у середовищі PYG, порівняно із контролем 10 днів при самостійному культивуванні бактерій за тих же умов. Варто також зазначити, що темпи росту амеб після 14 днів не змінювались. Це вказує на те, що S. tурhi не має цитотоксичного впливу по відношенню до $A$. castellanii. Ці результати демонструють те, що пов'язані з $A$. castellanii бактерії $\epsilon$ більш стійкими і амеби можуть сприяти збереженню сальмонел у навколишньому середовищі [17].

Pid Shigella. Можливість співіснування Sh. dysenteriae i Sh. sonnei з Acanthamoeba castellanii було підтверджено шляхом підрахунку життєздатних бактеріальних клітин після впливу антибіотика (гентаміцин) на суміш амеби-бактерії та з подальшим використанням електронної мікроскопії. Отримані результати експериментального дослідження показали, що Sh. dysenteriae та Sh. sonnei також здатні виживати в присутності амеб більше 3 тижнів. Використані шигели були нечутливими до впливу антимікробного препарата, отже, знаходилися всередині клітини Acanthamoeba castellanii, що було наочно продемонстровано за допомогою електронної мікроскопії: бактерії чітко візуалізувалися в цитоплазмі $A$. castellanii. Отже, цілком ймовірно, амеби відіграють значну роль у передачі бактерій роду Shigella в навколишньому середовищі [18]. Saeed A. et al. використовували Acanthamoeba castellanii як модель для вивчення вірулентності бактерій роду Shigella. Автори показали, що шигели за наявності різних факторів патогенності мають здатність контролювати спосіб загибелі клітин-хазяїв, оскільки вони прямо активували механізми, що призводили до апоптозу або некрозу аме6 [19].

Pодина Legionellaceae. В ряді літературних джерелах описано симбіотичні зв'язки L. pneumophila з вільноживучими найпростішими родів Hartmanella та Acanthamoeba. 3 використанням електронно-мікроскопічних та імунофлуоресцентних методів лабораторних досліджень було показано, що L. pneumophila розмножувалась винятково всередині трофозоїтів амеб. Методом електронної мікроскопії досліджено можливі варіанти розташування легіонел у внутрішньоклітинному середовищі найпростіших. Бактерії визначалися у фагосомах (включаючи клітини, що діляться), заповнювали цитоплазму або знаходились в інших частинах амебної клітини під час їх процесу інцистування [20, 21]. Акантамеби активно захоплювали і перетравлювали легіонели при температурі $20^{\circ} \mathrm{C}$. Бактерії зникали з культурального середовища на 2 добу при спільному культивуванні, проте до 6 доби знову з'являлись у середовищі в невеликій концентрації (10² КУО/мл). Отже, легіонели здатні до розмноження всередині амебної клітини та зберігають, таким чином, свою життєздатність [20]. Згідно з літературними даними, легіонели, перебуваючи в цитоплазмі найпростіших, можуть перешкоджати поділу клітини та реплікації ДНК останніх, а також змінювати їх морфологію [22]. Крім L. pneumophila досліджені легіонелоподібні амебні патогени (LLAPs), які ізолювали з клітин найпростіших. Свою назву вони отримали через схожу з легіонелами здатність до інвазії та розмноження в клітинах вільноживучих найпростіших. Вважають, що LLAPs $€$ обов'язковими внутрішньоклітинними бактеріальними паразитами вільноіснуючих аме6 [23].

Родина мусоbacteriaceae. Акантамеби вже тривалий час розглядають як резервуар мікобактерій у навколишньому середовищі. Для вивчення особливостей взаємодії представників родини Mycobacteriaceae та амеб були використані такі види: Mycobacterium tuberculosis, Mycobacterium avium, Mycobacterium leprae та Mycobacterium bovis [24-28]. Встановлено, що всі мікобактерії здатні виживати в клітині амеби як на стадії трофозоїта, так і цисти. Samba-Louaka A. et al. для визначення наявності M. avium підвиду paratuberculosis в амебах, які перебувають у навколишньому середовищі, відбирали зразки води фермерських угідь, де серед тварин реєструвалися захворювання на паратуберкульоз. Проведені молекулярно-генетичні дослідження показали, що в амебах та зразках від хворих тварин виділені тотожні бактерії. Це явище підтверджує, що амеби можуть бути век- 
Огляди літератури, оригінальні дослідження, погляд на проблему, випадок з практики, короткі повідомлення

тором передачі вказаного інфекційного захворювання [25]. Важливим є також факт збереження вірулентності штамів бактерій після взаємодії з найпростішими. Wheat W. et al. в експерименті 3 білими мишами, яким вводили мусobacterium leprae після 35-денного співкультивування 3 A. castellanii та A. polyphaga, показали, що у більшості тварин (80\%) з'явились ознаки захворювання. При мікроскопічному дослідженні біологічного матеріалу, взятого в лабораторних тварин, виявлено кислотостійкі бактерії, належність яких до мікобактерій підтверджена молекулярно-генетичними методами (ПЛР) [28]. Ці дані дозволяють зробити висновок, що мікобактерії можуть довго залишатися життєздатними у вільноживучих амебах та зберігати свою вірулентність.

Родина Pseudomonadaceae. Для визначення взаємовідносин вільноживучих амеб з бактеріями роду Pseudomonas sp. використовували 12 різних видів аме6. В результаті проведених молекулярно-генетичних досліджень з усіх зразків суспензій амеб була виділена ДНК псевдомонади [29]. Цей експеримент доводить належність псевдомонад до ряду бактерій, які здатні співіснувати з вільноживучими найпростішими. Dey et al., використовуючи електронну мікроскопію та проточну цитофлуориметрію, виявили псевдомонади у вакуолях акантамеби, що підтверджує належність псевдомонад до АРБ [30].

Родина Staphylococcaceae. Імовірність взаємодії між Acanthamoeba polyphaga i Staphylococcus aureus (MRSA) визначали шляхом тривалого спільного культивування бактерій та найпростіших. Амеби та стафілококи вирощували протягом 96 годин при $30^{\circ} \mathrm{C}$, відбираючи зразки через рівні проміжки часу (24, 48, 72, 96 год). Результати показали, що при контакті бактерій з найпростішими за вказаних умов існування кількість життєздатних амебних клітин знижувалася до 89 \%, тоді як розвиток стафілококів при контакті з трофозоїтами покращувався. Також встановлено, що лізат амебної культури (отриманий після 3 циклів заморожування при $-20{ }^{\circ} \mathrm{C}$, з подальшим розморожуванням) збільшує інтенсивність росту золотистого стафілокока, а супернатант амебної культури пригнічує ріст бактерій. Це явище вказує на те, що $A$. polyphaga утворює певні метаболіти, які впливають на інтенсивність росту бактерій. Описано також збільшення часу інцистування $A$. polyphaga в присутності бактерій S. aureus. Отримані результати показують, що A. polyphaga та S. aureus мають виражений взаємовплив на розвиток та метаболізм один одного [31].

Pодина Streptococcaceae. При вивчені взаємодіï S. pyogenes i S. pneumoniae з найпростішими виду $A$. castellanii виявлено, що обидва види стрептококів могли адсорбуватися на поверхні амебного трофозоїта, а також проникати та/або захоплюватись амебою. Варто зазначити, що S. pyogenes i S. pneumoniae зберігали свою життєздатність у процесі інцистування, уникали перетравлення, розмножувались всередині амебних клітин і були стійкішими у зрілих цистах, порівняно із стадією трофозоїта. A. castellanii також може виступати в якості вектора та/або резервуара для стрептококів, сприяючи їхньому росту та частковому обміну генетичною інформацією між ними. Крім того, дослідники припустили, що цей тип взаємодії не лише сприяє виживанню S. pyogenes i S. pneumoniae у навколишньому середовищі, а й впливає на їх вірулентність [32].

Родина Vibrionaceae. Вивчення взаємодії V. cholera з представниками вільноживучих найпростіших має важливе практичне значення. Як відомо, збудник холери передається в основному через водне середовище, яке інтенсивно заселяють вільноіснуючі амеби. Дослідження останніх років доводять, що V. cholerae серовар 0139 має внутрішньоклітинну сумісність 3 Acanthamoeba castellanii як еукаріотичним хазяїном. Це явище було підтверджено із застосуванням V. cholera ceрологічної групи О1 (біовари classic та El Tor). Обидва біовари могли виживати, перебуваючи в цитоплазмі трофозоїтів, а також були виявлені в цистах A. castellanii. Одержані результати дали змогу авторам зробити висновок, що V. cholerae O1 біоварів classic та El Tor $є$ факультативними внутрішньоклітинними бактеріями, а A. castellanii $\epsilon$ потенційним хазяїном для холерного вібріона [33]. У результаті вивчення впливу факторів адгезії та інвазії V. cholera 0139 Bengal (капсула та лПС) на розвиток цих бактерій всередині амебної клітини було показано, що жоден з вищенаведених факторів не впливав на симбіотичну взаємодію вібріонів та найпростіших [34]. Отже, вільноживучі амеби можуть бути хазяями і для даних бактерій у навколишньому середовищі, а фактори вірулентності V. cholera не впливають на взаємодію найпростіших та вібріонів.

Дослідження взаємодії вільноживучих амеб з представниками мікробного світу не обмежилося лише використанням бактерій. Зокрема, ряд наукових робіт присвячено вивченню можливої взаємодії вільноживучих амеб з патогенними для людей вірусами. В ході визначення здатності до співіснування даних мікроорганізмів постало питання про можливість амеб захоплювати вірусні частки, оскільки розміри практично всіх патогенних для людей вірусів, на відміну від бактерій, не перевищують межу фагоцитозу ( $\leq 250$ нм). Саме тому деякі автори досліджували взаємодію амеб не лише 3 віріонами, а й з клітинами, що уражені вірусом. 
Огляди літератури, оригінальні дослідження, погляд на проблему, випадок з практики, короткі повідомлення

Pid Adenovirus. Аденовіруси - патогенні для людини віруси, що викликають такі захворювання, як респіраторні інфекції, фарингокон'юнктивальна лихоманка, кон'юнктивіти, гастрити, цистити тощо. Для вивчення взаємодії аденовірусів 3 акантамебами використовували найпростіші (генотип Т4), ізольовані з водопровідної води та води плавальних басейнів, а також амеби з патогенним потенціалом від пацієнтів з амебним кератитом (штам LaHel2). Акантамеби культивували разом з аденовірусами 1, 2, 8, 11, 37 та 41 серотипів $[35,36]$. У результаті використання електронної та флуоресцентної мікроскопії було показано, що віруси після контакту з амебами локалізувалися в цитоплазмі трофозоїтів [35]. У наступних дослідженнях ідентифікація проводилась методом полімеразної ланцюгової реакції в реальному часі. Застосування цього підходу дозволило визначити генетичний матеріал аденовірусу в $62,5 \%$ амебних ізолятів [36]. Отже, враховуючи вищенаведені дані можна зробити висновок, що аденовіруси потрапляють у клітинне середовище амеб на стадії трофозоїта, а, перебуваючи всередині цисти, віруси, як і бактерії, захищені від дії різних пошкоджувальних факторів, включаючи дезінфектанти.

Pid Norovirus. Одним із найпоширеніших збудників гострих вірусних кишкових інфекцій $\epsilon$ норовіруси (норфолквіруси), які передаються через забруднену їжу або воду. Як і у випадку з холерним вібріоном, вивчення взаємодії акантамеб з норовірусами $\epsilon$ важливим питанням, оскільки вільноживучі амеби, постійно перебуваючи у водному середовищі, мають контакт з вірусними чинниками i можуть відігравати значну роль в епідеміологічному процесі поширення цієї інфекції. Для підтвердження цієї гіпотези в дослідженнях використали два види аме6: $A$. castellanii та $A$. polyphaga, а також похідні норовірусів - мишачий норовірус 1 (MNV-1) і котячий каліцівірус (FCL). Для індикації взаємодії використовували реакцію імунофлуоресценції, яка була проведена через 1 та 24 години після контакту обох чинників. У результаті проведеного дослідження було встановлено, що у вірусу MNV-1 процес переходу від зовнішньої поверхні амеби до її внутрішньої частини завершується вже через 24 години, тоді як FCL не виділявся вже через годину. Крім того, було досліджено тривалу взаємодію вірусу (протягом 8 діб) MNV-1 і показано, що вірус виживає після проходження амебою повного життєвого циклу (інцистування та ексцистування) [37]. Отже, вільноживучі амеби можуть сприяти підвищенню виживання норовірусів, як і ряду інших мікробних чинників.

Pid Enterovirus. Представники ентеровірусів здатні викликати низку інфекційних захворю- вань, вражаючи як травну, так і нервову системи. Серед ентеровірусів для визначення взаємодії з вільноіснуючими найпростішими використовували віруси Коксакі, ЕСНО та поліовірус. Експерименти з вірусом Коксакі В-3 (CVB-3), які оцінювали за допомогою реакції імунофлуоресценції, показали чудову адсорбцію вірусів на поверхні амеби та накопичення їх всередині трофозоїтів. Виживання вірусних агентів не залежало від динаміки реплікації амеб та їх інцистування. Крім того, результати експериментальної роботи показали, що інфіковані вірусом амеби можуть вивільняти інфекційні вірусні частки під час взаємодії їх з макрофагами людини [38]. Подальші вивчення взаємодії вірусів Коксакі та акантаме6, проведені M. Alotaibi, дали протилежні результати. В цьому дослідженні автор показав, що ентеровіруси здатні потрапляти в трофозоїти вільноживучих амеб лише в поєднанні з інфікованими клітинами ссавців, а не самостійно. Результати були отримані за допомогою молекулярно-генетичних та імунофлуоресцентних методів [39]. L. Danes та L. Cerva в умовах in vitro контамінували вирощену при кімнатній температурі Acanthamoeba castellanii людськими ентеровірусами (ECHO 4, 30 та поліовіруси 1 і 3 серотипів). Автори не виявили значного накопичення ентеровірусів на поверхні чи всередині амебної клітини при 21-денному спостережені. На основі даних реакції нейтралізації із специфічними сироватками дослідниками зробили висновок, що віруси, найімовірніше, знаходяться лише на поверхні амебної клітини. На думку авторів, клітинні форми найпростіших відігравали для вірусів лише роль твердофазного носія [40].

Pid Rotavirus. На сьогодні ротавіруси $€$ найпоширенішими збудниками вірусних кишкових інфекцій як серед дітей, так і серед дорослих. Оскільки віруси у великій кількості виділяються $з$ фекаліями інфікованих пацієнтів у зовнішнє середовище, то актуальним $\epsilon$ вивчення їх здатності до взаємодії з вільноживучими найпростішими. Проведені експериментальні мікроскопічні (імунофлуоресценція) дослідження показують, що трофозоїти амеб можуть захоплювати клітини, які інфіковані ротавірусами, натомість вільні вірусні частки не здатні проникати в клітини акантамеб. Таким чином, найпростіші роду Acanthamoeba можуть бути переносниками ротавірусів у людській популяції, оскільки при ротавірусних інфекціях вірус виділяється разом із інфікованими епітеліальними клітинами та надходить у стічні води, де i перебувають амеби [39].

На основі всебічного аналізу літературних джерел можна зробити висновок, що вільноживучі найпростіші мають специфічні способи взаємодії з різноманітними патогенними та умовно- 
Огляди літератури, оригінальні дослідження, погляд на проблему, випадок з практики, короткі повідомлення

патогенними мікроорганізмами. Результати численних експериментальних досліджень підтверджують, що акантамеби можуть виконувати роль резервуара для багатьох збудників інфекційних захворювань, а також бути фактором передачі їх до людей або тварин. Патогенні бактерії та віруси, які локалізуються в амебах, несуть приховану загрозу для здоров'я людей, оскільки вони $\epsilon$ недосяжними для лікарських засобів та нечутливі до дії згубних зовнішніх чинників і дезінфектантів.

\section{ЛІТЕРАТУРА}

1. Greub G. Microorganisms resistant to free-living amoebae10.1128/cmr.17.2.413-433.2004 / G. Greub, D. Raoult // Clin. Microbiol. Rev. - 2004. - Vol. 17, No. 2. P. 413-433.

2. Balczun C. Free-living amoebae as hosts for and vectors of intracellular microorganisms with public health significance / C. Balczun, P. L. Scheid // Viruses. - 2017. Vol. 9, No. 4.

3. Khan N. A. Acanthamoeba: biology and increasing importance in human health / N. A. Khan // FEMS Microbiology Reviews. - 2006. - Vol. 30, No. 4. - P. 564-595.

4. Król-Turmińska K. Human infections caused by free-living amoebae / K. Król-Turmińska, A. Olender // Annals of Agricultural and Environmental Medicine. - 2017. Vol. 24, No. 2. - P. 254-260.

5. Behera H. S. Isolation and genotyping of acanthamoeba spp. from acanthamoeba meningitis/ meningoencephalitis (ame) patients in india / H. S. Behera, G. Satpathy, M. Tripathi // Parasites and Vectors. - 2016. - Vol. 9, No. 1. - P. 4-9.

6. Successful treatment of sinusitis by acanthamoeba in a pediatric patient after allogeneic stem cell transplantation / A. Juan, L. Alonso, T. Olivé [et al.] // The Pediatric Infectious Disease Journal. - 2016. - Vol. 35, No. 12. P. 1350-1351.

7. Lambrecht E. Impact of acanthamoeba cysts on stress resistance of salmonella enterica serovar typhimurium, yersinia enterocolitica 4/o:3, listeria monocytogenes 1/2a, and escherichia coli o:26 / E. Lambrecht, J. Baré, K. Sabbe, K. Houf // Applied and Environmental Microbiology. - 2017. - Vol. 83, No. 14. - P. 1-9.

8. The conserved escrt-iii machinery participates in the phagocytosis of entamoeba histolytica / Y. Avalos-Padilla, R. L. Knorr, R. Javier-Reyna[et al.] // Frontiers in Cellular and Infection Microbiology. - 2018. - Vol. 8, No. March. - P. 1-17.

9. Siddiqui R. Acanthamoeba is an evolutionary ancestor of macrophages: a myth or reality? / R. Siddiqui, N. A. Khan // Experimental Parasitology. - 2012. - Vol. 130, No. 2. - P. 95-97.

10. Cosson P. Intracellular killing of bacteria: is dictyostelium a model macrophage or an alien? / P. Cosson, W. C. Lima // Cellular Microbiology. - 2014. - Vol. 16, No. 6. - P. 816-823.

11. Acanthamoeba castellanii is not be an adequate model to study human adenovirus interactions with macrophagic cells / E. Maisonneuve, E. Cateau, N. Leveque [et al.] // PLoS ONE. - 2017. - Vol. 12, No. 6. - P. 1-10.

12. Acanthamoeba spp. as a universal host for pathogenic microorganisms: one bridge from environment to host virulence / A. J. Guimaraes, K. X. Gomes, J. R. Cortines [et al.] // Microbiological Research. - 2016. - Vol. 193. P. 30-38.

13. Molmeret M. Amoebae as training grounds for intracellular bacterial pathogens / M. Molmeret, M. Horn, M. Wagner [et al.] // Applied and Environmental Microbiology. - 2005. - Vol. 71, No. 1. - P. 20-28.

14. Matin A. Interaction of escherichia coli k1 and k5 with acanthamoeba castellanii trophozoites and cysts / A. Matin, S. Y. Jung // Korean Journal of Parasitology. 2011. - Vol. 49, No. 4. - P. 349-356.

15. Somorin Y. Roles for rpos in survival of escherichia coli during protozoan predation and in reduced moisture conditions highlight its importance in soil environments / Y. Somorin, G. Bouchard, J. Gallagher[et al.] // FEMS Microbiology Letters. - 2017. - Vol. 364, No. 19. - P. 1-7.

16. Tezcan-Merdol D. Uptake and replication of salmonella enterica in acanthamoeba rhysodes / D. TezcanMerdol, M. Ljungström, J. Winiecka-Krusnell [et al.] // Applied and Environmental Microbiology. - 2004. - Vol. 70, No. 6. - P. 3706-3714.

17. Douesnard-Malo F. Increased persistence of salmonella enterica serovar typhi in the presence of acanthamoeba castellanii / F. Douesnard-Malo, F. Daigle // Applied and Environmental Microbiology. - 2011. - Vol. 77, No. 21. - P. 7640-7646.

18. Saeed A. Acanthamoeba castellanii an environmental host for shigella dysenteriae and shigella sonnei / A. Saeed, H. Abd, B. Edvinsson, G. Sandström // Archives of Microbiology. - 2009. - Vol. 191, No. 1. - P. 83-88.

19. Saeed A. Temperature depended role of shigella flexneri invasion plasmid on the interaction with acanthamoeba castellanii / A. Saeed, D. Johansson, G. Sandström, H. Abd // International Journal of Microbiology. 2012. - No. February 2012.

20. Interaction of $\mathrm{l}$. pneumophila and a free living amoeba (acanthamoeba palestinensis) / C. M. Anand, A. R. Skinner, A. Malic, J. B. Kurtz // Journal of Hygiene. 1983. - Vol. 91, No. 2. - P. 167-178.

21. Effects of cytochalasin $d$ and methylamine on intracellular growth of legionella pneumophila in amoebae and human monocyte-like cells / C. H. King, B. S. Fields, E. B. Shotts, E. H. White // Infection and Immunity. - 1991. Vol. 59, No. 3. - P. 758-763.

22. Legionella pneumophila prevents proliferation of its natural host acanthamoeba castellanii / L. Mengue, M. Régnacq, W. Aucher [et al.] // Scientific Reports. 2016. - Vol. 6, No. October. - P. 1-12.

23. Adeleke A. Legionella-like amebal pathogens phylogenetic status and possible role in respiratory disease / A. Adeleke, J. Pruckler, R. Benson [et al.] // Emerging Infectious Diseases. - 1996. - Vol. 2, No. 3. - P. 225-230. 
Огляди літератури, оригінальні дослідження, погляд на проблему, випадок з практики, короткі повідомлення

24. Mycobacterium tuberculosis complex mycobacteria as amoeba-resistant organisms / F. Mba Medie, I. Ben Salah, B. Henrissat [et al.] // PLoS ONE. - 2011. - Vol. 6, No. 6. - P. 1-7.

25. Samba-Louaka A. Environmental mycobacterium avium subsp. paratuberculosis hosted by free-living amoebae / A. Samba-Louaka, E. Robino, T. Cochard [et al.] // Frontiers in Cellular and Infection Microbiology. - 2018. Vol. 8, No. February. - P. 1-8.

26. Long-term survival and virulence of mycobacterium leprae in amoebal cysts / W. H. Wheat, A. L. Casali, V. Thomas [et al.] // PLoS Neglected Tropical Diseases. 2014. - Vol. 8, No. 12.

27. Lamrabet O. Acanthamoeba polyphaga-enhanced growth of mycobacterium smegmatis / O. Lamrabet, F. M. Medie, M. Drancourt // PLoS ONE. - 2012. - Vol. 7, No. 1. - P. 1-8.

28. Mycobacterium bovis hosted by free-living-amoebae permits their long-term persistence survival outside of host mammalian cells and remain capable of transmitting disease to mice / A. Sanchez-Hidalgo, A. ObregónHenao, W. H. Wheat [et al.] // Environmental Microbiology. - 2017. - Vol. 19, No. 10. - P. 4010-4021.

29. Pukatzki S. The human pathogen pseudomonas aeruginosa utilizes conserved virulence pathways to infect the social amoeba dictyostelium discoideum / S. Pukatzki, R. H. Kessin, J. J. Mekalanos // Proceedings of the National Academy of Sciences. - 2002. - Vol. 99, No. 5. - P. 3159-3164.

30. Dey R. Interactions of pseudomonas aeruginosa with acanthamoeba polyphaga observed by imaging flow cytometry / R. Dey, A. M. Rieger, C. Stephens, N. J. Ashbolt// Cytometry Part A. - 2019. - Vol. 95, No. 5. - P. 555-564.

31. Souza T. K. de Interaction between= methicillinresistant staphylococcus aureus (mrsa) and acanthamoeba polyphaga / T. K. de Souza, S. S. Soares, L. B. Benitez, M. B. Rott // Current Microbiology. - 2017. - Vol. 74, No. 5. - P. 541-549.

32. Siddiqui R. Acanthamoeba castellanii interactions with streptococcus pneumoniae and streptococcus pyo- genes / R. Siddiqui, T. Y. Yee Ong, S. Y. Jung, N. A. Khan // Experimental Parasitology. - 2017. - Vol. 183. - P. 128-132.

33. Abd $\mathrm{H}$. Vibrio cholerae 01 strains are facultative intracellular bacteria, able to survive and multiply symbiotically inside the aquatic free-living amoeba acanthamoeba castellanii / H. Abd, A. Saeed, A. Weintraub [et al.] // FEMS Microbiology Ecology. - 2007. - Vol. 60, No. 1. -P. 33-39.

34. Abd H. Vibrio cholerae o139 requires neither capsule nor lps o side chain to grow inside acanthamoeba castellanii / H. Abd, A. Saeed, A. Weintraub, G. Sandström // Journal of Medical Microbiology. - 2009. - Vol. 58, No. 1. P. 125-131.

35. Scheid P. Acanthamoeba spp. as vehicle and reservoir of adenoviruses / P. Scheid, R. Schwarzenberger // Рarasitology Research. - 2012. - Vol. 111, No. 1. - P. 479-485.

36. Staggemeier R. Detection and quantification of human adenovirus genomes in acanthamoeba isolated from swimming pools acanthamoeba, a free-living protozoan , is ubiquitous in water bodies, being characterized by high resistance to adverse environmental conditions, bei / R. Staggemeier, T. Arantes, K. S. Caumo // 2016. - P. 1-7.

37. Hsueh T.-Y. Interactions between human norovirus surrogates and acanthamoeba spp. / T.-Y. Hsueh, K. E. Gibson // Applied and Environmental Microbiology. 2015. - Vol. 81, No. 12. - P. 4005-4013.

38. Acanthamoeba castellanii promotion of in vitro survival and transmission of coxsackie b3 viruses / A. Mattana, C. Serra, E. Mariotti [et al.] // Eukaryotic Cell. - 2006. Vol. 5, No. 4. - P. 665-671.

39. Alotaibi M. A. Internalisation of enteric viruses by acanthamoeba castellanii, via ingestion of virus-infected mammalian cells / M. A. Alotaibi // Food and Environmental Virology. - 2011. - Vol. 3, No. 3-4. - P. 109-114.

40. Danes L. Survival of polioviruses and echoviruses in acanthamoeba castellanii cultivated in vitro / L. Danes, L. Cerva // Journal of Hygiene, Epidemiology, Microbiology, and Immunology. - 1981. - Vol. 25, No. 2. P. 169-74.

\section{REFERENCES}

1. Greub, G., \& Raoult, D. (2004). Microorganisms resistant to free-living amoebae. Clinical Microbiology Reviews, 17 (2), 413-433. doi: 10.1128/cmr.17.2.413-433.2004

2. Balczun, C., \& Scheid, P. (2017). Free-living amoebae as hosts for and vectors of intracellular microorganisms with public health significance. Viruses, 9 (4), 65. doi: $10.3390 / \mathrm{v} 9040065$

3. Khan, N. (2006). Acanthamoeba: biology and increasing importance in human health. FEMS Microbiology Reviews, 30 (4), 564-595. doi: 10.1111/j.15746976.2006.00023.x

4. Król-Turmińska, K., \& Olender, A. (2017). Human infections caused by free-living amoebae. Annals of $\mathrm{Ag}$ ricultural and Environmental Medicine, 24 (2), 254-260. doi:10.5604/12321966.1233568

5. Behera, H., Satpathy, G., \& Tripathi, M. (2016). Isolation and genotyping of Acanthamoeba spp. from
Acanthamoeba meningitis/meningoencephalitis (AME) patients in India. Parasites \& Vectors, 9 (1). doi: 10.1186/ s13071-016-1729-5

6. Juan, A., Alonso, L., Olivé, T., Navarro, A., Sulleiro, E., Sánchez de Toledo, J. and Díaz de Heredia, C. (2016). Successful treatment of sinusitis by acanthamoeba in a pediatric patient after allogeneic stem cell transplantation. The Pediatric Infectious Disease Journal, 35 (12), pp.13501351. doi:10.1097/inf.0000000000001329

7. Lambrecht, E., Baré, J., Sabbe, K., \& Houf, K. (2017). Impact of acanthamoeba cysts on stress resistance of Salmonella Enterica Serovar Typhimurium, Yersinia Enterocolitica 4/O:3, Listeria monocytogenes 1/2a, and Escherichia coli 0:26. Applied and Environmental Microbiology, 83 (14). doi: 10.1128/aem.00754-17

8. Avalos-Padilla, Y., Knorr, R., Javier-Reyna, R., GarcíaRivera, G., Lipowsky, R., Dimova, R., \& Orozco, E. (2018). The 
Огляди літератури, оригінальні дослідження, погляд на проблему, випадок з практики, короткі повідомлення

Conserved ESCRT-III Machinery Participates in the Phagocytosis of Entamoeba histolytica. Frontiers in Cellular and Infection Microbiology, 8. doi: 10.3389/fcimb.2018.00053

9. Siddiqui, R., \& Khan, N. (2012). Acanthamoeba is an evolutionary ancestor of macrophages: A myth or reality? Experimental Parasitology, 130 (2), 95-97. doi: 10.1016/j. exppara.2011.11.005

10. Cosson, P., \& Lima, W. (2014). Intracellular killing of bacteria: is Dictyosteliuma model macrophage or an alien? Cellular Microbiology, 16 (6), 816-823. doi: 10.1111/ cmi.12291

11. Maisonneuve, E., Cateau, E., Leveque, N., Kaaki, S., Beby-Defaux, A., \& Rodier, M. (2017). Acanthamoeba castellanii is not be an adequate model to study human adenovirus interactions with macrophagic cells. PLOS ONE, 12 (6), e0178629. doi: 10.1371/journal.pone.0178629

12. Guimaraes, A., Gomes, K., Cortines, J., Peralta, J., \& Peralta, R. (2016). Acanthamoeba spp. as a universal host for pathogenic microorganisms: One bridge from environment to host virulence. Microbiological Research, 193, 3038. doi:10.1016/j.micres.2016.08.001

13. Molmeret, M., Horn, M., Wagner, M., Santic, M., \& Abu Kwaik, Y. (2005). Amoebae as training grounds for intracellular bacterial pathogens. Applied and Environmental Microbiology, 71 (1), 20-28. doi: 10.1128/aem.71.1.2028.2005

14. Matin, A., \& Jung, S. (2011). Interaction of Escherichia coli K1 and K5 with Acanthamoeba castellanii Trophozoites and Cysts. The Korean Journal of Parasitology, 49 (4), 349. doi: 10.3347/kjp.2011.49.4.349

15. Somorin, Y., Bouchard, G., Gallagher, J., Abram, F., Brennan, F. and O'Byrne, C. (2017). Roles for RpoS in survival of Escherichia coli during protozoan predation and in reduced moisture conditions highlight its importance in soil environments. FEMS Microbiology Letters, 364 (19). doi:10.1093/femsle/fnx198

16. Tezcan-Merdol, D., Ljungstrom, M., Winiecka-Krusnell, J., Linder, E., Engstrand, L., \& Rhen, M. (2004). Uptake and Replication of Salmonella enterica in Acanthamoeba rhysodes. Applied And Environmental Microbiology, 70 (6), 3706-3714. doi: 10.1128/aem.70.6.3706-3714.2004

17. Douesnard-Malo, F., \& Daigle, F. (2011). Increased persistence of Salmonella enterica Serovar Typhi in the presence of Acanthamoeba castellanii. Applied and Environmental Microbiology, 77 (21), 7640-7646. doi: 10.1128/ aem.00699-11

18. Saeed, A., Abd, H., Edvinsson, B., \& Sandström, G. (2008). Acanthamoeba castellanii an environmental host for Shigella dysenteriae and Shigella sonnei. Archives of Microbiology, 191 (1), 83-88. doi: 10.1007/s00203-0080422-2

19. Saeed, A., Johansson, D., Sandström, G., \& Abd, H. (2012). Temperature depended role of shigella flexneriInvasion plasmid on the Interaction with acanthamoeba castellanii. International Journal of Microbiology, 2012, 1-8. doi: 10.1155/2012/917031

20. Anand, C., Skinner, A., Malic, A., \& Kurtz, J. (1983). Interaction of L. pneumophila and a free-living amoeba (Acanthamoeba palestinensis). Journal of Hygiene, 91 (02), 167-178. doi: 10.1017/s0022172400060174

21. Harold King, C., \& Barry S. Fields (1991) Effects of cytochalasin D and methylamine on intracellular growth of legionella pneumophila in amoebae and muman monocyte-like cells, Infection and Immunity, 59 (3), 758-763.

22. Mengue, L., Régnaca, M., Aucher, W., Portier, E., Héchard, Y., \& Samba-Louaka, A. (2016). Legionella pneumophila prevents proliferation of its natural host Acanthamoeba castellanii. Scientific Reports, 6 (1). doi: 10.1038/ srep36448

23. Adeleke, A. (1996). Legionella-like amebal pathogens-phylogenetic status and possible role in respiratory disease. Emerging Infectious Diseases, 2 (3), 225-230. doi: 10.3201/eid0203.960311

24. Mba Medie, F., Ben Salah, I., Henrissat, B., Raoult, D., \& Drancourt, M. (2011). Mycobacterium tuberculosis complex mycobacteria as amoeba-resistant organisms. Plos ONE, 6(6), e20499. doi: 10.1371/journal. pone.0020499

25. Samba-Louaka, A., Robino, E., Cochard, T., Branger, M., Delafont, V., \& Aucher, W. et al. (2018). Environmental mycobacterium avium subsp. paratuberculosis hosted by free-living amoebae. Frontiers in Cellular And Infection Microbiology, 8. doi: 10.3389/fcimb.2018.00028

26. Wheat, W., Casali, A., Thomas, V., Spencer, J., Lahiri, R., \& Williams, D. (2014). Long-term survival and virulence of mycobacterium leprae in amoebal cysts. Plos. Neglected Tropical Diseases, 8 (12), e3405. doi: 10.1371/ journal.pntd.0003405

27. Lamrabet, O., Medie, F., \& Drancourt, M. (2012). Acanthamoeba polyphaga-enhanced growth of mycobacterium smegmatis. Plos ONE, 7 (1), e29833. doi: 10.1371/ journal.pone.0029833

28. Sanchez-Hidalgo, A., Obregón-Henao, A., Wheat, W., Jackson, M., \& Gonzalez-Juarrero, M. (2017). Mycobacterium bovis hosted by free-living-amoebae permits their long-term persistence survival outside of host mammalian cells and remain capable of transmitting disease to mice. Environmental Microbiology, 19 (10), 4010-4021. doi: $10.1111 / 1462-2920.13810$

29. Pukatzki, S., Kessin, R., \& Mekalanos, J. (2002). The human pathogen Pseudomonas aeruginosa utilizes conserved virulence pathways to infect the social amoeba Dictyostelium discoideum. Proceedings of the National Academy of Sciences, 99 (5), 3159-3164. doi: 10.1073/ pnas.052704399

30. Dey, R., Rieger, A., Stephens, C., \& Ashbolt, N. (2019). Interactions of pseudomonas aeruginosa with Acanthamoeba polyphaga observed by imaging flow cytometry. Cytometry Part A, 95 (5), 555-564. doi: 10.1002/ cyto.a. 23768

31. de Souza, T., Soares, S., Benitez, L., \& Rott, M. (2017). Interaction between methicillin-resistant staphylococcus aureus (MRSA) and Acanthamoeba polyphaga. Current Microbiology, 74 (5), 541-549. doi: 10.1007/s00284017-1196-z

32. Siddiqui, R., Yee Ong, T., Jung, S., \& Khan, N. (2017). Acanthamoeba castellanii interactions with Streptococcus pneumoniae and Streptococcus pyogenes. Experimental Parasitology, 183, 128-132. doi: 10.1016/j.exppara.2017.08.005

33. Abd, H., Saeed, A., Weintraub, A., Nair, G., \& Sandstrom, G. (2007). Vibrio cholerae 01 strains are facultative intracellular bacteria, able to survive and multiply symbiotically inside the aquatic free-living amoeba Acantha- 
Огляди літератури, оригінальні дослідження, погляд на проблему, випадок з практики, короткі повідомлення moeba castellanii. FEMS Microbiology Ecology, 60 (1), 3339. doi: 10.1111/j.1574-6941.2006.00254.x

34. Abd, H., Saeed, A., Weintraub, A., \& Sandstrom, G. (2009). Vibrio cholerae 0139 requires neither capsule nor LPS O side chain to grow inside Acanthamoeba castellanii. Journal of Medical Microbiology, 58 (1), 125-131. doi: 10.1099/jmm.0.004721-0

35. Scheid, P., \& Schwarzenberger, R. (2012). Acanthamoeba spp. as vehicle and reservoir of adenoviruses. Parasitology Research, 111 (1), 479-485. doi: 10.1007/ s00436-012-2828-7

36. Staggemeier, R., Arantes, T., Caumo, K., Rott, M., \& Spilki, F. (2016). Detection and quantification of human adenovirus genomes in Acanthamoeba isolated from swimming pools. Anais Da Academia Brasileira De Ciências, 88 (suppl. 1), 635-641. doi: 10.1590/00013765201620150151

37. Hsueh, T., \& Gibson, K. (2015). Interactions between human norovirus surrogates and Acanthamoeba spp. Applied and Environmental Microbiology, 81 (12), 40054013. doi: $10.1128 /$ aem.00649-15

38. Mattana, A., Serra, C., Mariotti, E., Delogu, G., Fiori, P., \& Cappuccinelli, P. (2006). Acanthamoeba castellanii Promotion of In Vitro Survival and Transmission of Coxsackie B3 Viruses. Eukaryotic Cell, 5 (4), 665-671. doi: 10.1128/ec.5.4.665-671.2006

39. Alotaibi, M. (2011). Internalisation of enteric viruses by acanthamoeba castellanii, via ingestion of virusinfected mammalian cells. Food And Environmental Virology, 3 (3-4), 109-114. doi: 10.1007/s12560-011-9067-4

40. Danes L., \& Cerva L. (1981) Survival of polioviruses and echoviruses in Acanthamoeba castellanii cultivated in vitro. Journal of Hygiene, Epidemiology, Microbiology, and Immunology, 25 (2), 169-174.

\title{
АКАНТАМЕБЫ КАК РЕЗЕРВУАР ПАТОГЕННЫХ БАКТЕРИЙ И ВИРУСОВ (обзор литературы)
}

๑А. П. Чоботар

\author{
Национальный медицинский университет имени А. А. Богомольца, Киев
}

РЕЗюмЕ. Свободноживущие простейшие рода Acanthamoeba являются представителями многих микроэкологических групп объектов внешней среды и постоянно взаимодействуют с другими микроорганизмами (вирусами и бактериями), населяющими данные экологические ниши. Особенности этих взаимоотношений изучают исследователи всех стран мира уже более 20 лет. Исследовано ряд патогенных и условно-патогенных бактерий, которые способны сосуществовать с акантамебами. Описано симбиотическое взаимодействие амеб с энтеробактериями, микобактериями, легионеллами, псевдомонадами, стафилококками, стрептококками и рядом других прокариот. При сокультивированни простейших с бактериями увеличивается срок выживаемости последних и повышается их устойчивость к воздействию вредных факторов окружающей среды. Ряд научных работ посвящен также изучению взаимодействия Acanthamoeba sp. с представителями царства Vira, а именно родов Adenovirus, Norfolkvirus, Rotavirus и Enterovirus. Характер взаимодействия бактерий и вирусов с представителями свободноживущих простейших на клеточном уровне исследуется чаще всего с использованием микроскопических и современных молекулярно-генетических методов.

Цель - проведение анализа способности свободноживущих амеб взаимодействовать с бактериями и вирусами, а также исполнять роль резервуара для патогенных микроорганизмов.

Вывод. Подробный анализ литературных источников позволил сделать вывод, что свободноживущие амебы способны активно поглощать патогенные микроорганизмы. Доказано также, что свободносуществующие простейшие могут выполнять роль резервуара для патогенных микроорганизмов и служить вектором передачи возбудителей инфекционных заболеваний. Таким образом, амебы исполняют роль «троянского коня» микробного мира.

КЛЮчевЫЕ слОВА: Acanthamoeba sp.; сосуществование; бактерии; вирусы. 


\section{ACANTHAMOEBAE AS RESERVOIR OF PATHOGENIC BACTERIA AND VIRUSES (literature review)}

\section{A. P. Chobotar}

\section{O. Bohomolets National Medical University}

SUMMARY. The literature rewiew showed thet free-living protozoa species Acanthamoeba are representatives of large numbers of microecological groups in environmental objects and they constantly interact with other microorganisms (viruses and bacteria) that inhabit these ecological niches. The features of these relationships were studied for over 20 years. A number of pathogenic and opportunistic bacteria that can coexist with acanthamoebae are investigated. For example, the symbiotic interaction of amoeba with enterobacteria, mycobacteria, legionella, pseudomonadae, staphylococci, streptococci and a number of other prokaryotes is described. When co-cultivating the protozoa with bacteria increases the survival time of the latest and their resistance to the influence of harmful environmental factors. A number of scientific papers are also devoted to the study of the interaction of Acanthamoeba sp. with the representatives of the kingdom of Vira, especially the genera Adenovirus, Norfolkvirus, Rotavirus and Enterovirus. The nature of the interaction of bacteria and viruses with representatives of free living protozoa on the cellular level is most often studied by using microscopic and modern molecular genetic methods.

The aim of the study - to conduct the analysis of ability of free-living amoebae to interact with bacteria and viruses, and to act as a reservoir for pathogenic microorganisms.

Conclusion. A detailed analysis of literary sources made it possible to conclude that free-living amoebae are capable of actively absorbing pathogenic microorganisms. It is also proved that free-living amoebae can act as a reservoir for pathogenic microorganisms and serve as a vector for the transmission of pathogens of infectious diseases. Thus, amoebae act as a "Trojan horse" of the microbial world.

KEY WORDS: Acanthamoeba sp.; coexistence; bacteria; viruses. 